\begin{tabular}{cc|c}
\hline Tar. Bil. Der. & Journal of Agricultural Sciences \\
& $\begin{array}{c}\text { Dergi web sayfası: } \\
\text { www.agri.ankara.edu.tr/dergi }\end{array}$ & Journal homepage: \\
& www.agri.ankara.edu.tr/journal
\end{tabular}

\title{
The Effect of Sward Structure and N Fertilization on the Grass-legume Silage Quality
}

\author{
Zorica BIJELIĆa, Zorica TOMIĆa, Violeta MANDIĆa, Dragana RUŽIĆ-MUSLIĆa, Aleksandar SIMIĆb \\ Vesna KRNJAJA ${ }^{\text {a }}$ \\ anstitute for Animal Husbandry, Autoput 16, Zemun, Belgrade, R. SERBIA \\ ${ }^{b}$ Belgrade University, Faculty of Agriculture, Nemanjina 6, Zemun, Belgrade, R. SERBIA
}

\section{ARTICLE INFO}

Research Article

Corresponding Author: Zorica BIJELIĆ, E-mail: zonesh@gmail.com, Tel: +381 (11) 2670541

Received: 10 June 2014, Received in Revised Form: 30 December 2014, Accepted: 30 December 2014

\begin{abstract}
The effect of sward structure of the mixtures and nitrogen fertilization on grass-legume silage quality was investigated over two years. The study included Lucerne (Medicago sativa) in monoculture and in mixtures with cocksfoot (Dactylis glomerata), tall fescue (Festuca arundinacea) and sainfoin (Onobrychis sativa). Nitrogen fertilizer was applied to the field plots at four different rates: $0,70,140$ and $210 \mathrm{~kg} \mathrm{ha}^{-1}$. The quality of lucerne silage was inferior to lucerne silage mixed with grasses due to the greater content of ammonia nitrogen $\left(\mathrm{NH}_{3}-\mathrm{N}\right)$, acetic (AA) and butyric acids $(\mathrm{BA})$, and reduced content of the lactic acid (LA). Gradual increase of $\mathrm{N}$ fertilization significantly has increased the content of $\mathrm{NH}_{3}-\mathrm{N}, \mathrm{AA}$ and BA and decreased the content of LA.
\end{abstract}

Keywords: Grass-legume mixture; Silage quality; Sward mixtures; Fertilization

\section{Çim Yapısı ve N Gübrelemesinin Çim-Baklagil Silaj Kalitesine Etkisi}

\section{ESER BILGISİ}

Araştırma Makalesi

Sorumlu Yazar: Zorica BIJELIĆ, E-posta: zonesh@gmail.com, Tel: +381 (11) 2670541

Geliş Tarihi: 10 Haziran 2014, Düzeltmelerin Gelişi: 30 Aralık 2014, Kabul: 30 Aralık 2014

\section{ÖZET}

Silaj karışımındaki çim yapısı ve N gübrelemesinin silaj kalitesine etkisi 2 yıllık bir çalışma ile araştırılmıştır. Çalışmada monokültür olarak adi yonca (Medicago sativa) ve karım olarak da kamışsı yumak (Festuca arundinacea) domuz ayrığ 1 (Dactylis glomerata) ve korunga (Onobrychis sativa) bulundurulmuştur. Azotlu gübre 0, 70, 140 ve $210 \mathrm{~kg} \mathrm{ha}^{-1}$ dozlarında uygulanmıştır. Yüksek düzeyde amonyak azotu $\left(\mathrm{NH}_{3}-\mathrm{N}\right)$, asetik asit (AA), butirik asit (BA) ve daha düşük laktik asit (LA) içeriği nedeniyle adi yonca silajının kalitesi, adi yonca ile çim karışımı silajlarından düşük olmuştur. Artan miktarda $\mathrm{N}$ uygulamaları $\mathrm{NH}_{3}-\mathrm{N}$, AA ve BA miktarında önemli düzeyde artışa LA miktarında ise önemli düzeyde azalışa neden olmuştur.

Anahtar Kelimeler: Çim-baklagil karışımı; Silaj kalitesi; Çim karışımı; Gübreleme 


\section{Introduction}

Silage is animal feed rich in essential nutrients, resulting from fermentation of the chopped mass of different plant species by lactic acid bacteria fermentation in a given time period. The main substrates essential for increasing of lactic acid bacteria in number are sugars. These bacteria are one of the most important determinants for successful fermentation and production of high quality silage. Contrary to grasses that typically contain sufficient amounts of fermentable sugars, legumes are poor in sugars, which makes them difficult to ensile. This can be overcome by mixing legumes and grasses, which increases the sugar content in the silo mass, thus allowing ensiling of legumes. Therefore, the combined cultivation of legumes and grasses is very useful even it has some difficulties. However, there are many factors that directly or indirectly affect the fermentable characteristics of silage crops. For instance, different types of plants, and even different plant varieties, are characterized by different contents of easily fermentable sugars and fermentative properties, producing ensiled material of differing qualities. Weissbach (2003) argues that Lolium species have a high sugar content, so that these species may be added to the silo material of low fermentable value. Cocksfoot silage and mixtures of cocksfoot with lucerne have better quality characteristics than that of pure lucerne silage. Han et al (2006) have shown that silage made from cocksfoot and its mixtures with lucerne have a higher content of fermentable sugars compared to lucerne silage in two cuts. Testing a mixture of red clover with perennial (Lolium perenne) and annual ryegrass (Lolium multiflorum) and cocksfoot (Dactylis glomerata), Wyss (2004), concluded that ryegrasses had positive, and cocksfoot had negative impacts on the silage quality. Also, the same author Wyss (2006), comparing the fermentability of three legumes proved that white and red clover have higher fermentable coefficient than lucerne. Applied cultivation techniques and practices influence the fermentable properties of crops, and the content of water soluble sugars. $\mathrm{N}$ fertilization is one of the most common agricultural measures used to increase crop yields; however, it often has degrading effects on the fermentation process and silage quality. The negative effects of nitrogen are reflected through: increasing in the buffer capacity, the content of nonprotein nitrogen, readily soluble nitrogen and $\mathrm{NH}_{3}-\mathrm{N}$ (Tremblay et al 2005), reduction of fermentable sugar content in the silo material, reduction of the digestibility of silage (Keady et al 2000), as well as greater presence of harmful microorganisms and the production of mycotoxins (Bijelić 2009). In order to balance between high yield and good silage quality, it is necessary to find the levels of nitrogen that are required to meet these two objectives.

Therefore, the aim of this study was to evaluate the effect of botanical composition of the lucerne-grass mixtures and fertilization with different amounts of nitrogen on the herbage silage quality of lucerne and it mixtures with different grasses and legume.

\section{Material and Methods}

\subsection{Field and laboratory experiment}

This study was conducted at the Institute for Animal Husbandry, Belgrade, Serbia (44 $49^{\prime} 10^{\prime \prime} \mathrm{N}, 20^{\circ} 18^{\prime}$ $45^{\prime \prime}$ E) during 2010-2011. The study was organized as a randomized complete block design with four replications $(4 \times 4)$. In each replication, lucerne (Medicago sativa) was sown in monoculture (L) and in mixtures with grasses (Dactylis glomerata and Festuca arundinacea) and sainfoin (Onobrychis sativa) [LC-lucerne, cocksfoot (50:50); LCTlucerne, cocksfoot, tall fescue (33.3:33.3:33.3); LCTS-lucerne, cocksfoot, tall fescue, sainfoin $(25: 25: 25: 25)]$ in field plots of $10 \mathrm{~m}^{2}$. $\mathrm{N}$ fertilizer was applied to the field plots at four different rates: $0,70,140$ and $210 \mathrm{~kg} \mathrm{ha}^{-1}$. Half of the $\mathrm{N}$ fertilizer was applied at the beginning of the growing season and the other half after the first cut. Prior to cutting, samples of plant material were collected from 1 $\mathrm{m}^{2}$ areas from all plots for analysis of botanical composition. Plants were cut at the early flowering stage of lucerne.

Silage was prepared from the second cut. After 24 $\mathrm{h}$ wilting, the silage mass was chopped, and ensiled in 64 laboratory silos of $10 \mathrm{~L}$ volume (containers). 
To encourage better fermentation, bacterial-enzyme inoculant was used in the amount of $10 \mathrm{~g}+2 \mathrm{~L} \mathrm{H}_{2} \mathrm{O}$ $\mathrm{t}^{-1}$ of fresh herbage. The silo containers were closed immediately after filling. After 90 days silages were opened and samples were taken for chemical analyses.

\subsection{Determination of silage quality}

After the fermentation period, laboratory silos were opened and two samples of silage material were taken from each silo for chemical analysis. Dry matter content was determined by drying the samples at $105^{\circ} \mathrm{C}$ overnight. Crude protein content was determined according to Kjeldahl (AOAC 1990). Lactic acid (LA) and volatile fatty acids [acetic (AA) and butyric acid (BA)] were quantified by a gas chromatographic system (GC-2014, Shimadzu, Kyoto, Japan) equipped with flameionization detector and auto sampler and injection system, using a Nukol ${ }^{\mathrm{TM}}(30 \mathrm{~m} \times 0.53 \mathrm{~mm} \times 0.5 \mu \mathrm{m})$ capillary column (Supelco, Sigma-Aldrich Co.) (Faithfull 2002). Ammonia nitrogen was determined using the distillation method using a Kjeltec 1026 analyser and the $\mathrm{pH}$ value was measured with a Hanna Instruments HI 83141 pH meter. Silage quality class was determined by the Flieg score $($ Kılıç 1986). Flieg score $=[220+(2 \times$ silage dry matter (\%)-15)]-40×silage $\mathrm{pH}$ value. Flieg Score values between 85 and 100 denote very good quality silage; between 60 and 80 , good quality silage.

\subsection{Statistical analysis}

The data obtained were analysed using twofactorial analysis of variance (ANOVA) and the mean differences were tested with Fisher's Least Significant Difference (LSD) test (StatSoft 2007).

\section{Results and Discussion}

\subsection{Impact of sward plant mixture}

The structure of lucerne mixtures during the research changed (Table 1), depending on the sward maturity, competitive ability of species, resistance to various climatic conditions and their response to applied management practices.
Table 1- Botanical composition of grass-legume mixtures prior to cutting

Çizelge 1- Çim baklagil karışımlarının biçim öncesi botanik kompozisyonlarl

\begin{tabular}{lcccccc}
\hline & \multicolumn{3}{c}{2010} & & \multicolumn{3}{c}{2011} \\
\hline & $L$ & $G$ & $W$ & $L$ & $G$ & $W$ \\
\hline Mixture (M) & & & & & & \\
LC & 61.0 & 37.9 & 1.1 & 57.7 & 31.2 & 2.2 \\
LCT & 64.7 & 34.7 & 0.6 & 64.0 & 34.6 & 1.4 \\
LCTS & 70.2 & 28.8 & 1.0 & 59.7 & 38.6 & 1.7 \\
\hline
\end{tabular}

L, legumes; G, grasses; W, weeds

The grass-legume mixtures had no significant impact on the content of crude protein, $\mathrm{pH}$ or Flieg score of the resultant silages. Highly significant differences occurred in the content of $\mathrm{NH}_{3}-\mathrm{N}$, lactic, acetic and butyric acid (Table $2)$. One of the most important properties for sufficient fermentation in grasses and legumes is content of dry matter. By increasing the DM content, good silages can be made from legumes and grasses even with low acidification potential. However, DM content should be from 400-450 g $\mathrm{kg}^{-1}$, everything beyond that should be avoided (Weissbach 2003). In our research, DM content was higher in grass-legume silages than in lucerne silages. Obtained values did not exceed the value of $450 \mathrm{~g} \mathrm{~kg}^{-1}$, but in the second year of the study were slightly lower (Table 3 ). Lucerne silage had a significantly higher content of $\mathrm{NH}_{3}-\mathrm{N}$ compared to the other silages. The content of $\mathrm{NH}_{3}-\mathrm{N}$ in other silages ranged from $109.9 \mathrm{~g} \mathrm{~kg}^{-1} \mathrm{TN}$ in the lucerne and cocksfoot mixture, to $120.5 \mathrm{~g} \mathrm{~kg}^{-1} \mathrm{TN}$ in mixtures with sainfoin. The content of LA was the highest in the silage of lucerne and cocksfoot mixture $\left(31.5 \mathrm{~g} \mathrm{~kg}^{-1} \mathrm{DM}\right)$ and the lowest in pure lucerne silage (24.3 $\left.\mathrm{g} \mathrm{kg}^{-1} \mathrm{DM}\right)$. Lucerne silage had a significantly higher content of AA and BA compared to the other silages.

The sward mixture had significant impact on the contents of $\mathrm{NH}_{3}-\mathrm{N}$ and lactic acid in the silages, in the second year of study. Lucerne silage had the highest content of $\mathrm{NH}_{3}-\mathrm{N}\left(115.4 \mathrm{~g} \mathrm{~kg}^{-1} \mathrm{TN}\right)$ which was significantly higher than that of the mixture of 
Table 2- Impact of sward structure on grass-legume silage quality in 2010

Çizelge 2- 2010 yılında çim-baklagil karışımında çim yapısının silaj kalitesi üzerine etkisi

\begin{tabular}{lccccc}
\hline Mixture $(M)$ & LC & LCT & LCTS & $L$ & $\begin{array}{c}\text { Level of significance } \\
M\end{array}$ \\
\hline $\mathrm{DM}\left(\mathrm{g} \mathrm{kg}^{-1}\right)$ & 415.4 & 416.9 & 429.3 & 360.8 & $*$ \\
$\mathrm{CP}\left(\mathrm{g} \mathrm{kg}^{-1} \mathrm{DM}\right)$ & 167.1 & 168.0 & 173.0 & 165.1 & $\mathrm{~ns}$ \\
$\mathrm{NH}_{3}-\mathrm{N}\left(\mathrm{g} \mathrm{kg}^{-1} \mathrm{TN}\right)$ & 112.8 & 109.9 & 120.5 & 123.5 & $* *$ \\
$\mathrm{LA}\left(\mathrm{g} \mathrm{kg}^{-1} \mathrm{DM}\right)$ & 31.5 & 26.6 & 27.3 & 24.3 & $* *$ \\
$\mathrm{AA}\left(\mathrm{g} \mathrm{kg}^{-1} \mathrm{DM}\right)$ & 15.0 & 18.6 & 14.9 & 19.7 & $* *$ \\
$\mathrm{BA}\left(\mathrm{g} \mathrm{kg}^{-1} \mathrm{DM}\right)$ & 0.00 & 0.04 & 0.00 & 0.07 & $* *$ \\
$\mathrm{pH}$ & 4.8 & 4.8 & 4.8 & 4.8 & $\mathrm{~ns}$ \\
Flieg score & 95.9 & 95.7 & 97.7 & 90.7 & $\mathrm{~ns}$ \\
\hline
\end{tabular}

$\mathrm{DM}$, dry matter; CP, crude protein; TN, total nitrogen; LA, lactic acid; AA, acetic acid; BA, butyric acid; ns, non significant; *, P $\leq 0.05$; $* *, \mathrm{P} \leq 0.01$

lucerne with cocksfoot and lucerne with cocksfoot and tall fescue. The content of LA, as in the first year of the study, was the highest in lucerne-cocksfoot mixture silage and lowest in the pure lucerne, respectively. The content of BA was higher than in the first year of the study, while the $\mathrm{pH}$ was lower, what is the probably related to lower DM content. All silages, as in the previous year, were scored as very good quality (Table 3).

In the research of Heikkilä et al (1992), the addition of legumes to the plant mixture reduced the content of $\mathrm{NH}_{3}-\mathrm{N}$ in silage. Therefore, silage obtained from the mixture of meadow fescue and timothy had a higher content of $\mathrm{NH}_{3}-\mathrm{N}$ than grass- clover silage (48 $\mathrm{g} \mathrm{kg}^{-1} \mathrm{TN}$ and $36 \mathrm{~g} \mathrm{~kg}^{-1} \mathrm{TN}$, respectively). However, in research by OrozcoHernández et al (1997), lucerne silage had a significantly higher content of $\mathrm{NH}_{3}-\mathrm{N}$, from 59 and $216 \mathrm{~g} \mathrm{~kg}^{-1} \mathrm{TN}$ in relation to timothy silage of 46 and cocksfoot of $172 \mathrm{~g} \mathrm{~kg}^{-1} \mathrm{TN}$. According to Lättemäe $\&$ Tamm (2002) the content of $\mathrm{NH}_{3}-\mathrm{N}$ in silage from mixed swards increases if the legumes ratio in the mixture increases. The physiological characteristics of legumes, the fact that they contain more $\mathrm{N}$ substances, and grasses contain more soluble sugars, can explain the significant differences in acid contents between lucerne silage and silage of its mixtures (Wilman \& Wright 1983). In fact,

Table 3- Impact of sward mixture on grass-legume silage quality in 2011

Çizelge 3- 2011 yılında çim-baklagil karışımında çim yapısının silaj kalitesi üzerine etkisi

\begin{tabular}{lccccc}
\hline Mixture $(M)$ & LC & LCT & LCTS & $L$ & $\begin{array}{c}\text { Level of significance } \\
\text { DM }\left(\mathrm{g} \mathrm{kg}^{-1}\right)\end{array}$ \\
$\mathrm{CP}\left(\mathrm{g} \mathrm{kg}^{-1} \mathrm{DM}\right)$ & 317.6 & 320.1 & 340.7 & 311.3 & $\mathrm{~ns}$ \\
$\mathrm{NH}_{3}-\mathrm{N}\left(\mathrm{g} \mathrm{kg}^{-1} \mathrm{TN}\right)$ & 156.9 & 154.9 & 172.5 & 174.6 & $*$ \\
$\mathrm{LA}\left(\mathrm{g} \mathrm{kg}^{-1} \mathrm{DM}\right)$ & 91.3 & 104.8 & 113.6 & 115.4 & $* *$ \\
$\mathrm{AA}\left(\mathrm{g} \mathrm{kg}^{-1} \mathrm{DM}\right)$ & 31.4 & 27.4 & 27.6 & 25.8 & $* *$ \\
$\mathrm{BA}\left(\mathrm{g} \mathrm{kg}^{-1} \mathrm{DM}\right)$ & 10.3 & 11.4 & 11.8 & 12.7 & $\mathrm{~ns}$ \\
$\mathrm{pH}$ & 0.01 & 0.01 & 0.02 & 0.09 & $\mathrm{~ns}$ \\
Flieg score & 4.6 & 4.6 & 4.6 & 4.6 & $\mathrm{~ns}$ \\
\hline
\end{tabular}

DM, dry matter; CP, crude protein; TN, total nitrogen; LA, lactic acid; AA, acetic acid; BA, butyric acid; ns, non significant; *, P $\leq 0.05$; **, $\mathrm{P} \leq 0.01$ 
Heikkilä et al (1992), comparing the quality of silage of clover-grass mixtures with grass mixtures, concluded that clover-grass mixtures contained more $\mathrm{CP}$ and less crude fibre and lactic acid content. In this study, a mixture of grass and lucerne yielded better quality silage compared to pure lucerne. Also a mixture of lucerne and grasses with sainfoin had better silage performance than pure lucerne, which is consistent with the results of Wang et al (2007), who claim that incorporation of sainfoin into lucerne forage improve fermentation.

\subsection{Impact of nitrogen fertilization and its interaction with sward mixtures on silage quality}

$\mathrm{N}$ fertilization had a significant impact $(\mathrm{P}<0.01)$ on the content of $\mathrm{NH}_{3}-\mathrm{N}, \mathrm{LA}$ and $\mathrm{BA}$. The control silage had a significantly lower content of $\mathrm{NH}_{3}-\mathrm{N}$ in comparison to the other silages, whereas the silage fertilized with $210 \mathrm{~kg} \mathrm{~N} \mathrm{ha}^{-1}$ had significantly higher $\mathrm{NH}_{3}-\mathrm{N}$ content compared to the silages which received less N (Table 4). Keady \& Kiely (1998) concluded that $\mathrm{N}$ fertilization has a detrimental effect on the quality of silage, because it increases the level of protein degradation, and the content of $\mathrm{NH}_{3}-\mathrm{N}$. In a study of the silage quality of timothy fertilized with $0,60,120$ and $180 \mathrm{~kg} \mathrm{~N} \mathrm{ha}^{-1}$, Tremblay et al (2005) concluded that the $\mathrm{NH}_{3}-\mathrm{N}$ content increased under the influence of the fertilization by 0.85 times.

In well-fermented clover - grass silages, the LA content ranges from $2.28-3.90 \%$, the AA content up to $5.5 \%$ and BA from $0-0.12 \mathrm{~g} \mathrm{~kg}^{-1} \mathrm{DM}$ (Djordjević $\&$ Dinić 2003). In relation to this statement, the LA content in the silages produced in the current study was satisfactory. The highest LA content occurred in the control and silage fertilized with $70 \mathrm{~kg} \mathrm{~N} \mathrm{ha}^{-1}$, and the lowest in silage fertilized with $210 \mathrm{~kg} \mathrm{~N} \mathrm{ha}^{-1}$. The BA content was relatively low (Table 4). According to Weissbach (2003), this could be explained by the fact that crop fertilized with $\mathrm{N}$ always contains some nitrate. That nitrate is partly reduced to nitrite in the silo which protects silage from butyric acid fermentation. Interaction of investigated factors by increasing share of legumes in the mixture and addition of $\mathrm{N}$ fertilizer significantly increased the concentration of ammonia nitrogen and acetic acid and decreased the concentration of lactic acid.

In the second year, fertilization led to significant changes $(\mathrm{P}<0.01)$ in $\mathrm{NH}_{3}-\mathrm{N}$ content, and the contents of LA and AA (Table 5). The content of $\mathrm{NH}_{3}-\mathrm{N}$ was significantly higher in silages fertilized with $210 \mathrm{~kg} \mathrm{~N}^{-1}$ (129.4 $\mathrm{g} \mathrm{kg}^{-1} \mathrm{TN}$ ) compared to the other silages. Silages from the control and from sward fertilized with $70 \mathrm{~kg} \mathrm{~N}^{-1}$ contained below $100 \mathrm{~g} \mathrm{~kg}^{-1} \mathrm{TN}$ of $\mathrm{NH}_{3}-\mathrm{N}$, which is characteristic of high-quality silage (Haigh \& Parker 1985) LA and AA contents in silage, influenced by $\mathrm{N}$-fertilization, were affected differently. Gradual increase of $\mathrm{N}$ fertilization has increased the content of acetic acid and decreased the content of lactic acid in silage. This is probably associated with the reduction of

Table 4- Impact of $\mathbf{N}$ fertilization on grass-legume silage quality in $\mathbf{2 0 1 0}$

Çizelge 4- 2010 yılında N gübrelemesinin çim-baklagil karışımında silaj kalitesi üzerine etkisi

\begin{tabular}{lrrrrrr}
\hline \multirow{2}{*}{$N$ fertilization $(N)$} & \multicolumn{3}{c}{70} & 140 & 210 & \multicolumn{2}{c}{ Level of significance } \\
\cline { 2 - 6 } & \multicolumn{3}{c}{$k g \mathrm{ha}^{-1}$} & & $\mathrm{~N}$ & Interaction $M x N$ \\
\hline $\mathrm{DM}\left(\mathrm{g} \mathrm{kg}^{-1}\right)$ & 411.5 & 370.9 & 422.4 & 417.5 & $\mathrm{~ns}$ & $\mathrm{~ns}$ \\
$\mathrm{CP}\left(\mathrm{g} \mathrm{kg}^{-1} \mathrm{DM}\right)$ & 174.2 & 169.6 & 172.3 & 171.2 & $\mathrm{~ns}$ & $\mathrm{~ns}$ \\
$\mathrm{NH}_{3}-\mathrm{N}\left(\mathrm{g} \mathrm{kg}^{-1} \mathrm{TN}\right)$ & 95.0 & 116.2 & 114.8 & 140.6 & $* *$ & $* *$ \\
$\mathrm{LA}\left(\mathrm{g} \mathrm{kg}^{-1} \mathrm{DM}\right)$ & 30.0 & 30.8 & 25.1 & 23.8 & $* *$ & $* *$ \\
$\mathrm{AA}\left(\mathrm{g} \mathrm{kg}^{-1} \mathrm{DM}\right)$ & 16.7 & 16.6 & 17.4 & 17.5 & $\mathrm{~ns}$ & $* *$ \\
$\mathrm{BA}\left(\mathrm{g} \mathrm{kg}^{-1} \mathrm{DM}\right)$ & 0.00 & 0.01 & 0.10 & 0.00 & $* *$ & $* *$ \\
$\mathrm{pH}$ & 4.8 & 4.8 & 4.7 & 4.9 & $\mathrm{~ns}$ & $\mathrm{~ns}$ \\
Flieg score & 96.1 & 92.2 & 100.5 & 91.1 & $\mathrm{~ns}$ & $\mathrm{~ns}$ \\
\hline
\end{tabular}

DM, dry matter; CP, crude protein; TN, total nitrogen; LA, lactic acid; AA, acetic acid; BA, butyric acid; ns, non significant; *, $\mathrm{P} \leq 0.05$; **, $\mathrm{P} \leq 0.01$ 
Table 5- Impact of $\mathbf{N}$ fertilization on grass-legume silage quality in $\mathbf{2 0 1 1}$

Çizelge 5- 2011 yılında N gübrelemesinin çim-baklagil karışımında silaj kalitesi üzerine etkisi

\begin{tabular}{lrrrrrr}
\hline \multirow{2}{*}{$N$ fertilization $(N)$} & 0 & \multicolumn{7}{c}{70} & 140 & \multicolumn{2}{c}{210} & \multicolumn{2}{c}{ Level of significance } \\
\cline { 2 - 6 } & 323.3 & 317.8 & 312.0 & 336.6 & $\mathrm{~ns}$ & $\mathrm{~ns}$ \\
\hline $\mathrm{DM}\left(\mathrm{g} \mathrm{kg}^{-1}\right)$ & 153.1 & 160.4 & 170.4 & 174.9 & $\mathrm{~ns}$ & $\mathrm{~ns}$ \\
$\mathrm{CP}\left(\mathrm{g} \mathrm{kg}^{-1} \mathrm{DM}\right)$ & 86.5 & 97.7 & 114.5 & 129.4 & $* *$ & $* *$ \\
$\mathrm{NH}_{3}-\mathrm{N}\left(\mathrm{g} \mathrm{kg}^{-1} \mathrm{TN}\right)$ & 32.0 & 28.6 & 25.1 & 25.2 & $* *$ & $* *$ \\
$\mathrm{LA}\left(\mathrm{g} \mathrm{kg}^{-1} \mathrm{DM}\right)$ & 10.1 & 9.6 & 12.8 & 11.8 & $* *$ & $* *$ \\
$\mathrm{AA}\left(\mathrm{g} \mathrm{kg}^{-1} \mathrm{DM}\right)$ & 0.00 & 0.01 & 0.03 & 0.09 & $\mathrm{~ns}$ & $\mathrm{~ns}$ \\
$\mathrm{BA}\left(\mathrm{g} \mathrm{kg}^{-1} \mathrm{DM}\right)$ & 4.6 & 4.5 & 4.6 & 4.6 & $\mathrm{~ns}$ & $\mathrm{~ns}$ \\
$\mathrm{pH}$ & 84.1 & 89.2 & 82.3 & 88.9 & $\mathrm{~ns}$ & $\mathrm{~ns}$ \\
Flieg score & & &
\end{tabular}

DM, dry matter; CP, crude protein; TN, total nitrogen; LA, lactic acid; AA, acetic acid; BA, butyric acid; ns, non significant; *, P $\leq 0.05$; **, $\mathrm{P} \leq 0.01$

herbage water soluble carbohydrates in nitrogen treatments (WSC) pre-ensiling (King et al 2013) and according to Keady et al (2000) lactic acid concentration is positively correlated with herbage WSC. The $\mathrm{pH}$ of the silages was higher in the first year of the study, which is more advantageous from the viewpoint of quality.

The results of the present study indicate that nitrogen fertilization had no effect on the $\mathrm{pH}$ value. The authors, Keady \& O'Kiely (1996), in their research report that $\mathrm{N}$ fertilization increased the $\mathrm{pH}$ value of the silage probably as a result of an increase of ammonia nitrogen content, which is of an alkali nature. In the present study, the lack of effect of $\mathrm{N}$ fertilization on the $\mathrm{pH}$ of silage, according to the Keady et al (2000) could be explained by an increase in the crude protein content fraction of the herbage at ensiling with increasing $\mathrm{N}$ fertilizer rate (Bijelić et al 2014). In assessing the quality of silage according to Flieg, taking into account the dry matter content and $\mathrm{pH}$, silages were shown to be influenced by fertilization treatment better in the first than in the second year of the study.

The amount of $\mathrm{NH}_{3}-\mathrm{N}$ in pure lucerne silage, mixtures thereof and from different fertilization treatments, is usually above the established values of $100 \mathrm{~g} \mathrm{~kg}^{-1} \mathrm{TN}$ for high-quality silages. Considering this fact, in the evaluation of the silage quality, it would be beneficial to use a score that includes this parameter of quality, especially when it comes to ensiling plants with high protein content such as the mixtures included in the present study.

The interaction of $\mathrm{N}$-fertilization rates and sward content in both study years had a highly significant impact $(\mathrm{P} \leq 0.01)$ on $\mathrm{NH}_{3}-\mathrm{N}$ and volatile fatty acid contents. Lucerne and mixture silages with a higher share of legumes had higher contents of $\mathrm{NH}_{3}-\mathrm{N}, \mathrm{AA}$ and BA, and lower contents of LA if fertilized with high rates of $\mathrm{N}$, which is in accordance with the results of King et al (2013).

\section{Conclusions}

Flieg quality silage score showed no significant difference in the quality of lucerne silage and its mixtures with grasses. However, the content of the quality parameters that are not included in the assessment indicate that the lucerne silage was of lower quality than silages from mixed sward. Lucerne silage had a significantly higher content of ammonia nitrogen, acetic and butyric acid. Although it is not clear in the quality assessment of the silage that adding high $\mathrm{N}$ rates diminished the quality of silage, they did act negatively on the content of some quality parameters, such as increasing the levels of $\mathrm{NH}_{3}-\mathrm{N}$ and $\mathrm{AA}$, and reducing the amounts of LA. Considering that the main objective of nitrogen fertilization is obtaining high yields, in order to meet the economic aspect of production and still get good quality silage, in the production of grass- 
legume mixture one should opt for the lower levels of nitrogen fertilization. In agroecological conditions where the lucerne is superior to its mixtures in regard to the DM yield, owing to better quality of silages made of mixtures compared to pure lucerne silage, the use of lucerne mixtures is justified.

\section{Acknowledgements}

This research is part of the Project TR-31053 financially supported by Ministry of Education, Science and Technological Development of the Republic of Serbia.

\section{References}

AOAC (1990). Official methods of analysis. K. Helrich, ed. 15 th ed. AOAC, Arlington,VA

Bijelić Z (2009). The influence of the mixture structure, nitrogen fertilization and utilization phase on quality parameters of grass-legume silages. $\mathrm{PhD}$ Thesis, University of Belgrade, R. Serbia

Bijelić Z, Tomić Z, Ružic-Muslić D, Krnjaja V, Mandić V, Vučković S \& Nikšić D (2014). Forage quality and energy content of perennial legume-grass mixtures at three level of $\mathrm{N}$ fertilization. Biotechnology in Animal Husbandry 30: 539-547

Djordjević N \& Dinić B (2003). Siliranje leguminoza, Institut za istraživanja u poljoprivredi SRBIJA, Beograd

Faithfull N (2002). Methods in Agricultural Chemical Analysis: A Practical Handbook, CABI Publishing, Wallingford

Haigh P M \& Parker J W G (1985). Effect of silage additives and wilting on silage fermentation, digestibility and intake, and on liveweight change of young cattle. Grass and Forage Science 40: 429-436

Han K J, Collins M, Vanzant E S \& Dougherty C T (2006). Characteristics of baled silage made from first and second harvests of wilted and severely wilted forages. Grass and Forage Science 61: 22-31

Heikkilä T, Toivonen V \& Mela T (1992). Comparison of red clover-grass silage with grass silage for milk production. In: Proceedings of the 14th General meeting of the European Grassland Federation, June 8-11, Lahti, pp. 388-391

Keady T W J \& Kiely P O (1996). An evaluation of the effects of rate of nitrogen fertilization of grassland on silage fermentation, in-silo losses, effluent production and aerobic stability. Grass and Forage Science 51: $350-362$

Keady T W J \& Kiely P O (1998). An evaluation of potassium and nitrogen fertilization of grassland and date of harvest on fermentation effluent production, dry matter recovery and predicted feeding value of silage. Grass and Forage Science 53: 326-337

Keady T W J, Mayne C S \& Fitzpatrick D A (2000). Prediction of silage feeding value from the analysis of the herbage at ensiling and effect of nitrogen fertilizer, date of harvest and additive treatment on grass silage composition. Journal of Agricultural Science, Cambridge 134: 353-368

Kılıç A(1986). Silo Yemi (Öğretim, Öğrenim ve Uygulama Önerileri). 340 s. Bilgehan Basımevi, Izmir, Turkey.

King C, McEniry J, Richardson M \& O'Kiely P (2013). Silage fermentation characteristics of grass species grown under two nitrogen fertilizer inputs and harvested at advancing maturity in the spring growth. Grassland Science 59: 30-43

Lättemäe P \& Tamm U (2002). The improvement of lucerne silage quality by using additives and lucernegrass mixtures. Agraarteadus 13(6): 337-342

Orozco-Hernandez J R, Brisson G J \& Girard V (1997). Timothy grass or lucerne silage for cows in midlactation: effect of supplementary barley. Journal of Dairy Science 80: 2876-2884

StatSoft (2007). STATISTICA, version 8.0, from http:// www.statsoft.com

Tremblay G F, Belanger G \& Drapeau R (2005). Nitrogen fertilizer application and developmental stage affect quality of timothy (Phleum pratense L.). Grass and Forage Science 60: 337-355

Wang Y, Barbieri L R, Berg B P \& McAllister T A (2007). Effect of mixing sainfoin with alfalfa on ensiling, ruminal fermentation and total tract digestion of silage. Animal Feed Science and Technology 135: 296-314

Weissbach H F (2003). Theory and practice of ensuring good quality of silages from grass and legumes. In: Proceedings of the XI. International scientific symposium "Forage Conservation", September 9-11, Nitra, pp. 31-36

Wilman D \& Wright P T (1983). Some effects of applied nitrogen on the growth and chemical composition of temperate grasses. Herbage Abstracts 53: 387-393

Wyss U (2004). Ensilability of different grass-clover mixtures. Grassland Science in Europe 9: 966-968

Wyss U (2006). Ensilability and silage quality of different grasses and legumes. Agrarforschung 13: 442-447 